
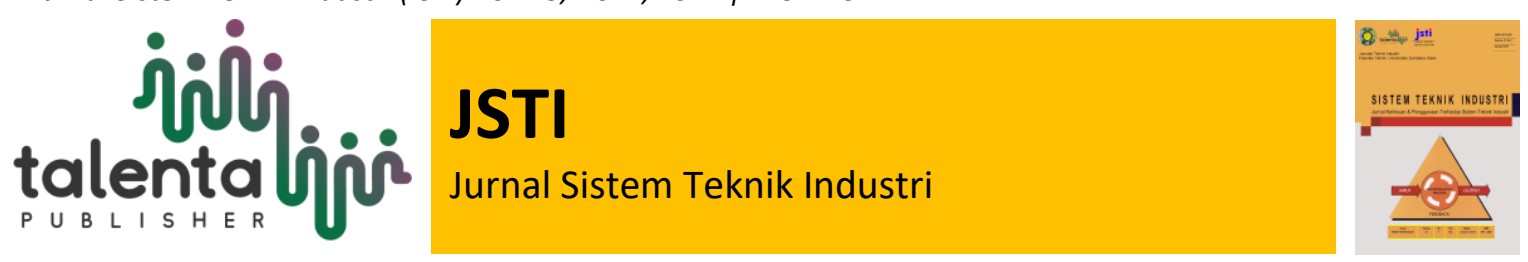

\title{
Feasibility Study of Public Health Center X
}

\author{
Willy Tambunan ${ }^{1}$, Theresia Amelia Pawitra ${ }^{2}$, Riko Yehezkiel Siagian ${ }^{3}$ \\ 1,2,3 Department of Industrial Engineering, Faculty of Engineering, Universitas Mulawarman, Jalan \\ Sambaliung No. 9, Samarinda 75119, Indonesia
}

\begin{abstract}
Public Health Center X is the first level health facility service provider in subdistrict X. Established in 1975, UPT Puskesmas X has never conducted a feasibility study which has been regulated since 2014. Based on these problems, this study aims to conduct a feasibility study on a new building. Aspects contained in Permenkes No. 75 of 2014 namely aspects of location, buildings, facilities and infrastructure, health equipment, personnel, and organization. There is a health center design stage which is made in accordance with the criteria of the Minister of Health No. 75 of 2014. Based on the results of research conducted on the new building of Public Health Center X, it is known that the location aspect meets $87.5 \%$ of the location criteria, the building aspect meets $100 \%$ of the building suitability, the facilities and infrastructure aspect meets $100 \%$ of the eligibility criteria, the equipment aspect only meets $34 \%$ of the equipment that must be owned, the manpower aspect fulfills $73 \%$ of the total workforce owned, and the organizational aspect meets 100\% of the conformity of the organizational structure, so that overall Public Health Center $\mathrm{X}$ has a feasibility percentage of $82.4 \%$. Public Health Center X needs to evaluate and improve. Improvements were made to the location aspect, namely, parking facilities by increasing the capacity of the parking lot. Then do the procurement and purchase of medical equipment because there are still $66 \%$ of equipment that is lacking, as well as adding health workers to the positions of public health workers, environmental health workers, and workers.
\end{abstract}

Keyword: Public Health Center; First Health Service Facilities; Feasibility Study; Permenkes Number 75 of 2014; Design.

\begin{abstract}
Abstrak. UPT Puskesmas X merupakan penyedia layanan fasilitas kesehatan tingkat pertama di kecamatan X. Berdiri sejak tahun 1975, UPT Puskesmas X belum pernah melakukan studi kelayakan yang diatur sejak tahun 2014. Berdasarkan permasalahan tersebut penelitian ini bertujuan untuk melakukan studi kelayakan pada bangunan baru. Aspek yang terdapat pada Permenkes No. 75 tahun 2014 yaitu aspek lokasi, bangunan, sarana dan prasarana, peralatan kesehatan, ketenagaan, dan organisasi. Terdapat tahap perancangan puskesmas yang dibuat sesuai dengan kriteria Permenkes No. 75 tahun 2014. Berdasarkan hasil penelitian yang dilakukan pada bangunan baru UPT Puskesmas X, maka diketahui aspek lokasi memenuhi 87,5\% kriteria lokasi, aspek bangunan memenuhi 100\% kesesuaian bangunan, aspek sarana dan prasarana memenuhi 100\% kriteria kelayakan, aspek peralatan hanya memenuhi $34 \%$ peralatan yang harus dimiliki, aspek ketenagaan memenuhi $73 \%$ jumlah tenaga kerja yang dimiliki, dan aspek organisasi memenuhi $100 \%$ kesesuaian struktur organisasi, sehingga secara keseluruhan UPT Puskesmas X memiliki persentase kelayakan sebesar 82,4\%. UPT Puskesmas X perlu melakukan evaluasi dan perbaikan. Perbaikan dilakukan pada aspek lokasi yaitu, fasilitas parkir dengan melakukan penambahan kapasitas lahan parkir. Kemudian melakukan pengadaan dan pembelian peralatan kesehatan karena masih terdapat $66 \%$ peralatan yang kurang, serta menambah
\end{abstract}

\footnotetext{
*Corresponding author at: Prodi Teknik Industri, Fakultas Teknik, Universitas Mulawarman, Jalan Sambaliung No. 9, Samarinda 75119, Indonesia

E-mail address: willytambunan@ft.unmul.ac.id, triciapawitra@gmail.com, rikoyehezkielsiagian@yahoo.co.id https://doi.org/10.32734/jsti.v23i2.6391 Attribution-NonCommercial 4.0 International. Some rights reserved Copyright @ 2021 Published by Talenta Publisher, ISSN: 1411-5247 e-ISSN: 2527-9408

Journal Homepage: http://talenta.usu.ac.id/jsti
} 
tenaga kesehatan pada posisi tenaga kesehatan masyarakat, tenaga kesehatan lingkungan, dan perkarya.

Kata Kunci: Puskesmas; Fasilitas Pelayanan Kesehatan Tingkat Pertama; Studi Kelayakan; Permenkes No. 75/2014; Perancangan.

Received 04 June 2021 | Revised 30 June 2021 | Accepted 19 July 2021

\section{Introduction}

The Public Health Center (Puskesmas) is one of the most important public health service facilities in Indonesia. According to Citra (2017) [1] Puskesmas is a health service facility that organizes public health efforts and first-level individual health efforts, by prioritizing promotive and preventive efforts. Puskesmas aims to achieve the highest level of public health in the working area of the puskesmas. According to Sardjoko (2018) [2] the function of the Puskesmas is to carry out health efforts that are comprehensive, integrated, equitably acceptable and affordable by the community with active community participation and using the results of the development of appropriate science and technology, at a cost that can be borne by the government and the wider community, without neglecting the quality of service to individuals.

From 1968 to 2000, puskesmas were managed and fostered by the central government (Ministry of Health). The construction of facilities, the placement of personnel, and the procurement of drugs for puskesmas are stipulated through a Presidential Instruction (Inpres). With the Presidential Instruction system, the distribution of puskesmas is evenly distributed in almost every sub-district. The policy has changed since the implementation of decentralization in 2000. According to the Juwiring Health Center (2017) [3] the management and development of the puskesmas is left to the district/city local government. Since then, the development of puskesmas has varied depending on local fiscal commitments and capabilities. The problem that stands out is the void or lack of human resources (HR) compared to the HR standards of the puskesmas.

According to Bappenas (2018) [4] the demands of the community's needs for health services are in accordance with the provisions, the West Kutai Government builds puskesmas facilities in every sub-district in West Kutai. One of the places is the Technical Implementation Unit (UPT) of Puskesmas X. UPT Puskesmas X itself was established in 1975 which aims to meet the health needs of the people of Kecamatan X. UPT Puskesmas X has 2 buildings, the old building which has been used since 1975 is no longer used for operational activities. The operational activities of UPT Puskesmas X have been moved to a new building since February 2020. In 2019, UPT Puskesmas X carried out the construction of a new building with the aim of moving operational activities from the old building. However, UPT Puskesmas $\mathrm{X}$ has not conducted a feasibility study for the new building and all aspects of the puskesmas. A feasibility study is a requirement set by the Ministry of Health with the aim that Puskesmas can meet the criteria that have been imposed by the Government. The Government Decree is contained in Permenkes No. 75 of 2014 [5]. 
Therefore, this research will conduct a feasibility study on the new building of UPT Puskesmas $\mathrm{X}$. With the aim that the puskesmas can meet the criteria for puskesmas according to Permenkes Number 75 of 2014 both for existing buildings and operational activities that support puskesmas.

The purpose to be achieved in this research are as to identify whether UPT Puskesmas X has met the eligibility criteria in Permenkes No. 75 in 2014 or not and to provide improvement recommendations.

\section{Methodology}

This research will be carried out in several stages consisting of preparation steps, data collection, data processing, analysis and discussion as well as closing steps. An explanation of each stage will be explained below.

\subsection{Preparation Step}

The first step that must be done in this research is preparation. At this stage consists of several steps:

1. Preliminary Study

Preliminary study is the initial stage in research. At this stage, a literature study is carried out regarding the research to be carried out, which is related to the feasibility study. Sources in conducting literature studies are Permenkes No. 75 of 2014, and in the form of similar research derived from books and literature obtained through the internet.

2. Problem Identification

Problem identification is carried out based on the results of observations made and then the results can be proposed in solving the problem, namely how the design of the puskesmas is in accordance with the criteria in Permenkes No. 75 of 2014, and whether the new building of UPT Puskesmas X is feasible based on Permenkes No. 75 Year 2014.

3. Determining Research Objectives

Determining research objectives depends on the formulation of the problem that has been determined so that it can assist researchers in achieving the desired final results. The purpose of this research is to design a health center in accordance with the Minister of Health Regulation No. 75 of 2014, analyzes the feasibility of new buildings and operations at UPT Puskesmas X, and provides recommendations for improvement of existing deficiencies.

4. Determination of Limits

Determination of problem boundaries aims to focus the discussion in research to make it clearer and structured so that it does not go out of the topic under study. In this study, there are limitations to the problem, namely, the feasibility study is only carried out on the new building of UPT Puskesmas X, and only until the building construction process is completed. 


\subsection{Data Collection}

At the data collection step, the types of data collected are divided into two. The data are primary data and secondary data. Below is the description.

1. Primary Data

Primary data is data obtained directly from the original source without going through an intermediary. Primary data in this study is divided into 2 (two), namely, observation and interviews.

- Observation

Observation is an observation activity that is carried out directly on the object of research. Observations were made to determine the conditions directly at the UPT Puskesmas X. The data obtained in the observation consisted of geographical criteria, transportation accessibility, parking facilities, security facilities, other conditions, building design, room conditions, air conditioning systems, lighting systems, communication systems, systems medical gases, and fire protection systems.

- Interview

In addition to observation, primary data was also obtained through an interview process conducted with the head of the Puskesmas UPT Puskesmas X. Interviews were conducted to obtain information that was not obtained through the observation process, such as transportation accessibility conditions, availability of public utilities provided by the government such as water resources, electricity, and telephone lines, environmental health management by providing WWTP and infectious and noninfectious waste management, ventilation systems and room air conditions when operational activities are carried out, sanitation systems, noise control systems.

2. Secondary Data

Secondary data is data obtained through intermediary media or indirectly. Secondary data in this study can be seen below.

- $\quad$ Supporting Documents

Supporting documents are needed to support information on primary data. Supporting documents consist of IMB, operational permit, land certification, profile, UPL, building plans, infrastructure documents, inventory list, medical equipment data, list of human resources, organizational structure, and SK organizational structure.

- $\quad$ Literature Study

Literature studies are needed to help solve the problems contained in the research with various references and relevant theories.

\subsection{Data Processing}

The next stage is to perform data processing, based on the data that has been obtained. The following are the stages of data processing which are described below. 
1. Building layout

In the layout there are 2 coefficients that are measured. Here is the description.

- $\quad$ Basic Building Coefficient (KDB)

At the KDB puskesmas the maximum is $60 \%$ of the total land owned. The way to measure KDB is by dividing the total land area by the total building area and then multiplying by $100 \%$.

- $\quad$ Building Floor Coefficient (KLB)

At puskesmas, the maximum KLB is 1.8. The method of measuring the KLB is the area of the entire floor then divided by the area of the land.

2. Air Conditioning System

In the air conditioning system, $\mathrm{ACH}$ calculations are carried out to determine the amount of air exchange, with a minimum standard of 12 exchanges per hour.

3. Lighting system

In the lighting system, the luminance level is calculated in unit lux.

\subsection{Feasibility Study}

At the feasibility study stage, measurements and feasibility assessments are carried out on every aspect and criteria contained in UPT Puskesmas X. In the feasibility study there are 2 (two) steps, namely:

\section{Health Center Design}

Based on the data that has been obtained, it is known the process in the design of the Puskesmas. The design of the puskesmas was carried out based on the criteria in Permenkes No. 75 of 2014. The criteria in each of these aspects produce a health center that is suitable for operational activities. These aspects consist of aspects of location, buildings, facilities and infrastructure, health equipment, personnel, and organization.

2. Health Center Conformity Analysis and Design

The Puskesmas suitability analysis and design was carried out by assessing the suitability of the existing puskesmas with Permenkes No. 75 of 2014 which has been realized in the design of the puskesmas. Aspects of the feasibility study analyzed are aspects of location, building, facilities and infrastructure, health equipment, personnel, and organization.

\section{Result and Discussion}

According Ermawati (2015) [6] feasibility study conducted to obtain projected needs and demand as well as assessing appropriate or not appropriate puskesmas is held or developed views of the aspects of location and environment, human resources, and Permenkes no. 75 of 2014. The assessment of the feasibility study is not based on one aspect, but all aspects are an important part of the feasibility assessment. In the feasibility study there are 2 (two) stages, namely, the design 
of the puskesmas and the analysis of the suitability of the building with the design. The following is a description of each stage.

\subsection{The design of the Puskesmas}

UPT Puskesmas X occupies an area of $2,815.5 \mathrm{~m}^{2}$, with a building permit on the available land. The following is the design stage of the health center.

\section{Location Aspects}

In the location aspect, considerations are made by assessing location criteria, such as geographical criteria, accessibility of transportation routes, land contours, parking facilities, security facilities, availability of public utilities, environmental health management, and other conditions. After designing all existing criteria, it is known the layout of the entire land in the design of the puskesmas by considering the existing criteria and land forms according to the journal Bupala (2015) [7], Hidayat (2012) [8], and Pambudi (2015) [9]. The following is an image of the overall layout which can be seen in Figure 1.

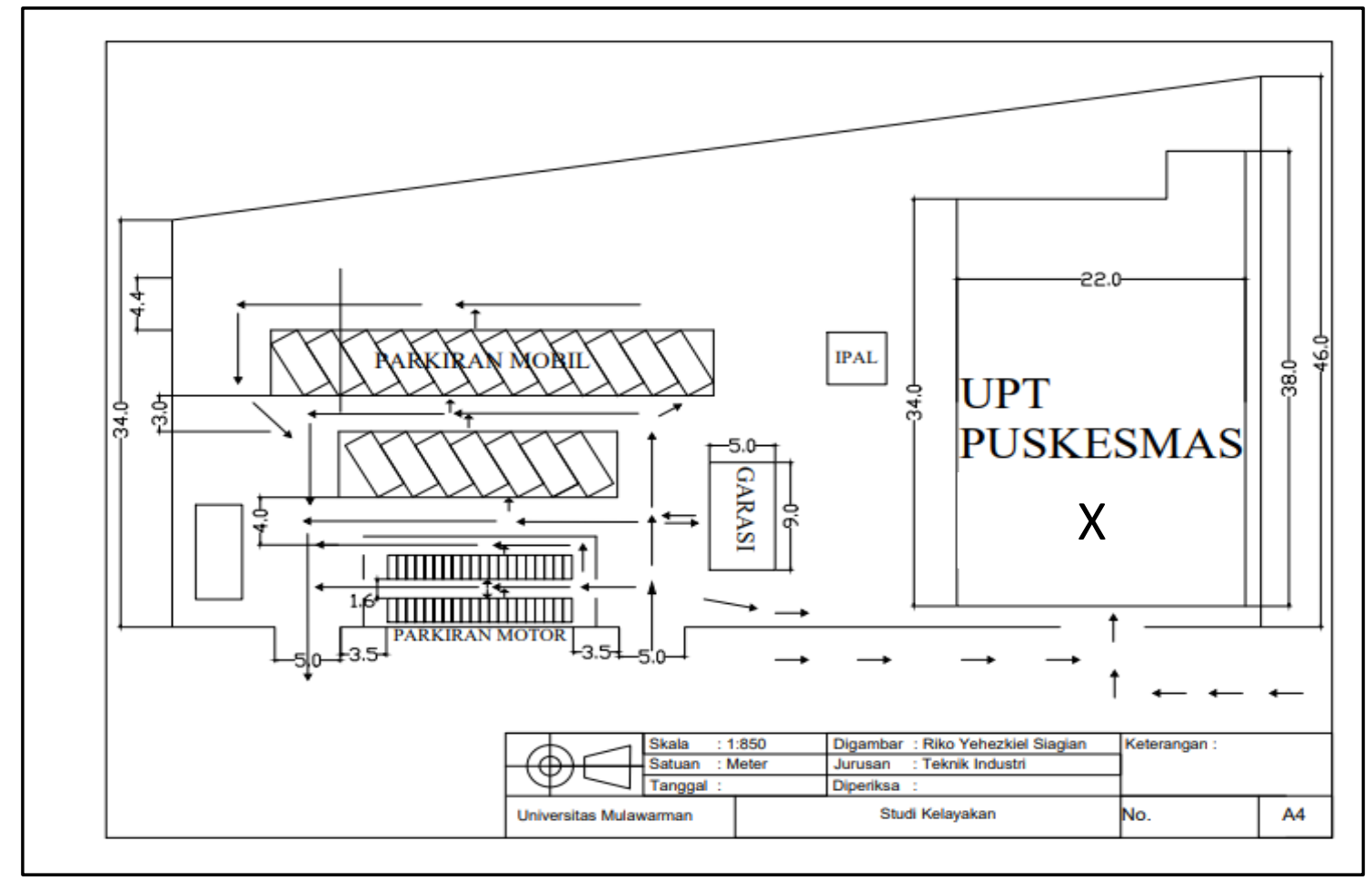

Figure 1 Layout of the Overall Land Plan for UPT Puskesmas X

\section{Building Aspects}

In the building aspect, the layout design and equipment layout in each room is carried out thoroughly. The standard used in the building layout design process is Permenkes No. 75 of 2014 as stated in the Ministry of Health's Technical Guidelines (2013) [10]. The following is the layout of the UPT Puskesmas X building in Figure 2. 


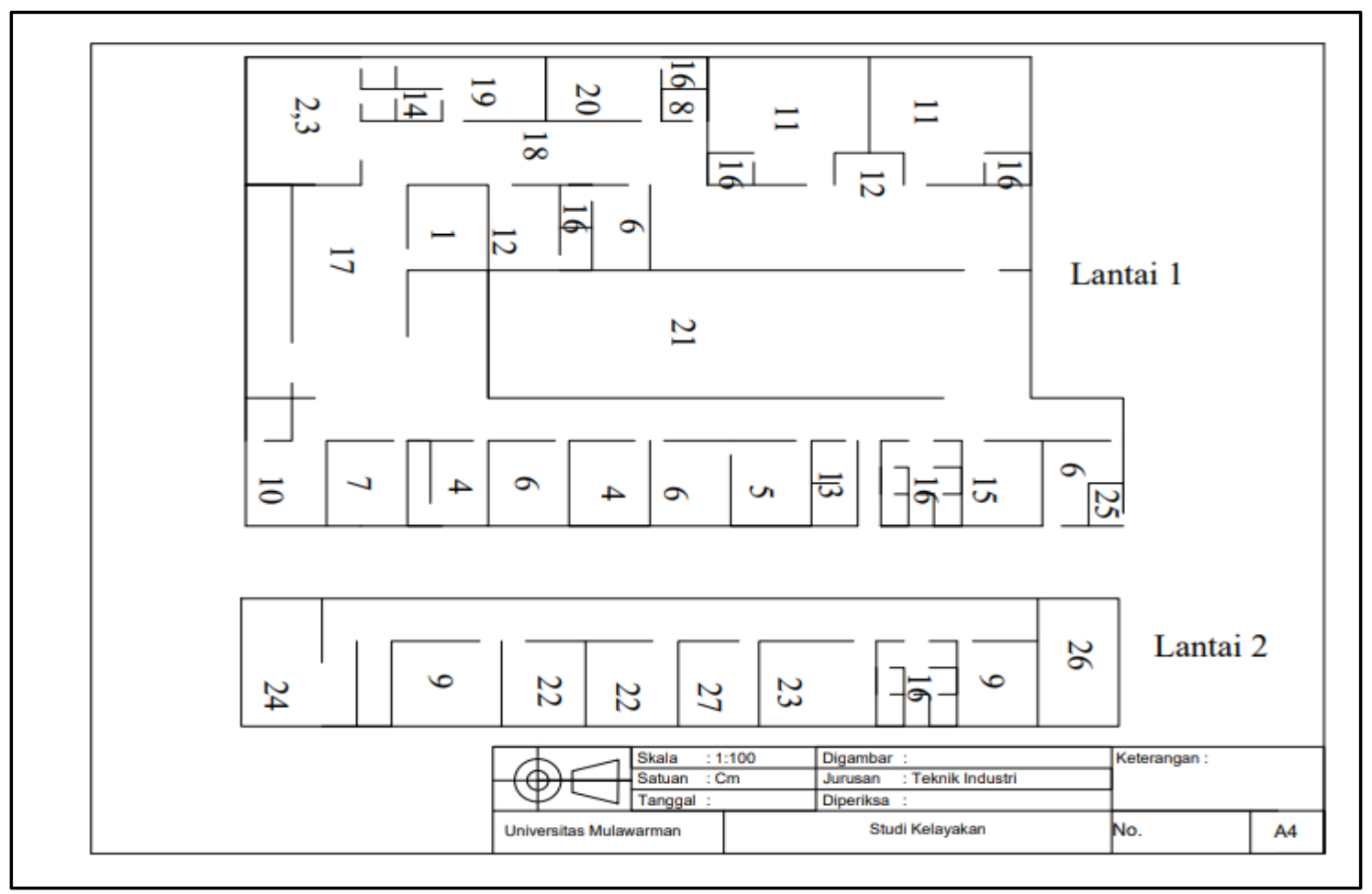

Figure 2 Layout Design of UPT Puskesmas X

3. Aspects of Facilities and Infrastructure

The design of facilities and infrastructure is carried out by considering each system in the puskesmas. The systems in question are ventilation systems, lighting, sanitation, electricity, communications, medical gases, lightning protection, fire protection, noise control, and vertical transportation within the puskesmas. All of these criteria follow the standards in Permenkes No. 75 years 2014.

4. Aspects of Health Equipment

Health equipment is important in an effort to support public health services. Health centers require health equipment according to the standards of the Minister of Health No. 75 of 2014 concerning health centers. Therefore, puskesmas must be able to meet the minimum standards that have been set. Determination of health equipment is regulated in every room in the puskesmas as well as activities outside the puskesmas. The design is done by procuring the necessary medical equipment.

5. Aspects of Man power

Public health centers' human resources consist of health workers and non-health workers. The types and numbers of health workers and non-health workers are calculated based on workload analysis, taking into account the number of services provided, population and distribution, characteristics of the work area, work area area, availability of other first-level health service facilities in the work area, and the division of work time. . The following is the number and type of workforce that must be met based on Permenkes number 75 of 2014 based on population density data for sub-district x according to Sofyan (2017) [11] which can be seen in Table 1 . 
Table 1 Minimum number of personnel

\begin{tabular}{llc}
\hline No & \multicolumn{1}{c}{ Type of Workforce } & Minimum Standard \\
\hline 1 & Doctor or primary care doctor & 1 \\
2 & Dentist & 1 \\
3 & Nurse & 5 \\
4 & Midwife & 4 \\
5 & Community health worker & 1 \\
6 & Environmental health worker & 1 \\
7 & Medical laboratory technology expert & 1 \\
8 & Nutritionist & 1 \\
9 & Pharmacy staff & 1 \\
10 & Administrative staff & 2 \\
11 & Workers & 1 \\
\hline
\end{tabular}

6. Organizational Aspects

The organization of the puskesmas is arranged by the district/city health office based on categories, health efforts and the workload of the puskesmas. The following is the minimum organizational structure that must be owned by a puskesmas based on Permenkes number 75 of 2014 concerning Community Health Centers, namely, the head of the puskesmas, the head of the administrative sub-section, the person in charge of SMEs and public health nursing, the person in charge of developing SMEs, the person in charge of UKP, pharmacy and laboratory and the person in charge of the puskesmas service network and the network of health service facilities.

\subsection{Health Center Conformity Analysis and Design}

The analysis carried out is in the form of a suitability analysis between the conditions contained in the UPT Puskesmas X with Permenkes No. 75 of 2014 which has been realized in the design of the puskesmas.

\section{Location Aspects}

The results of the feasibility of UPT Puskesmas X on the location aspect are that they have met the location criteria. Then it is known, UPT Puskesmas X can meet 7 of 8 criteria in the aspect of location or with a percentage of $87.5 \%$ with 2 criteria that have records. The criteria that are met are geography, accessibility of transportation routes, land contours, security facilities, availability of public utilities, environmental health management, and other conditions. 2 criteria that have records are the criteria for accessibility of transportation routes that do not have pedestrian paths and disability lanes, and security facilities that only meet the minimum requirements of having concrete fences. The criteria that are not met in the location aspect are parking facilities, improvements need to be made so as not to interfere with operational activities.

\section{2. $\quad$ Building Aspects}

The results of the feasibility of UPT Puskesmas X on the building aspect are feasible or with a percentage of $100 \%$. UPT Puskesmas X all criteria can be met starting from the criteria for 
building architecture, building design, symbols, rooms, building components and materials, and building structures.

3. Facilities and Infrastructure Aspects

The results of the feasibility of UPT Puskesmas X on the aspect of facilities and infrastructure are declared feasible or with a percentage of $100 \%$. All criteria can be met starting from the air conditioning system, lighting, sanitation, electricity, communication, medical gas, fire protection, noise control, vertical transportation.

4. Equipment Aspects

In terms of equipment, UPT Puskesmas X has not met the standards set by Permenkes No. 75 of 2014 in every workspace. UPT Puskesmas X only fulfills $34 \%$ of the equipment that must be owned. Data on equipment that needs to be procured can be seen in appendix 2 of data on medical devices.

5. Manpower Aspects

In the aspect of manpower, UPT Puskesmas $X$ still requires additional positions for public health workers, environmental health workers, and workers who do not have personnel to fill these positions with an eligibility percentage of $73 \%$, so that the manpower aspect does not meet the standards of Minister of Health Regulation No. 75 years 2014.

6. Organizational Aspects

In terms of personnel, UPT Puskesmas X has met the standards set by the Minister of Health Regulation No. 75 of 2014 or has a percentage of $100 \%$. However, there is a note for UPT Puskesmas $\mathrm{X}$ because there are several people who have more than one division position.

\section{Conclusions}

Based on the results of the analysis that has been carried out, it can be concluded that from the aspect of location, building, facilities and infrastructure, equipment, personnel, and organization, UPT Puskesmas X has not met the feasibility study standards of Puskesmas, because there are still criteria that cannot be met and are conditionally eligible. with a total eligibility percentage of $82.4 \%$. Therefore, Puskesmas X needs to make a thorough improvement so that the standards set in Permenkes No. 75 of 2014 concerning health centers. Then, recommendations for things that need to be improved by UPT Puskesmas X, aspects of location, aspects of health equipment, aspects of personnel, andcreation database.

Suggestions that can be given from the results of the study are that the Health Service and UPT Puskesmas X regularly update data. The goal is that when conducting research, the data information held is the same as the conditions in the field. In addition, immediate improvements will be made, such as the provision of parking facilities, medical equipment, and a shortage of medical personnel. This is done so that the quality of service at UPT Puskesmas X can be optimal. 


\section{REFERENCES}

[1] C. W., Dasar-dasar Pusat Kesehatan Masyarakat (Puskesmas) Edisi 1, Bali: Universitas Udayana, 2017.

[2] S. Sardjoko, Penguatan Pelayanan Kesehatan Dasar Di Puskesmas. Jakarta: Direktorat Kesehatan dan Gizi Masyarakat, 2018.

[3] P. Juwiring., Analisis Kebutuhan Pendirian Puskesmas Dan Pertimbangan Tata Ruang Daerah Dalam Pendirian Puskesmas, 2017.

[4] Bappenas, Peningkatan Akses Masyarakat Terhadap Kesehatan yang Berkualitas, 2018. [Accessed at 15 Oktober 2020].

[5] Kementerian Kesehatan, Permenkes No. 75 Tahun 2014. Jakarta; Yankes.aspak.kemkes.go.id, 2014.

[6] F. Ernawati, "Evaluasi Kelayakan Fasilitas Kesehatan Tingkat Pertama (FKTP) Dalam Program Jaminan Kesehatan Nasional (JKN) Berdasarkan Aspek Kredensialing (Studi Kasus Di Puskesmas Arjasa Kabupaten Jember.” Jawa Timur: Repository UNEJ, 2015.

[7] Bupala and Mudra, "Hibah Penelitian Jurusan Arsitektur Tahun 2015 Studi Kelayakan Teknis Dan Ekonomi Rencana Pembangunan Rumah Sakit Tipe D Pratama Di Kecamatan Seririt, Kabupaten Buleleng.” Bali: Universitas Udayana Jurnal, 2015.

[8] Y. A. Messah, R. A. L Kanny, and A. H. Rizal, "Analisis Kebutuhan Lahan Parkir Di Rumah Sakit Umum Daerah.” Jurnal Teknik Sipil, 1 (4), pp.87-100, 2012.

[9] L. Sriharyani and W. Pambudi, "ANALISA RUANG PARKIR KENDARAAN PADA RUMAH SAKIT UMUM DAERAH JENDERAL AHMAD YANI KOTA METRO." TAPAK (Teknologi Aplikasi Konstruksi): Jurnal Program Studi Teknik Sipil, 5 (1), 2016.

[10] Kementerian Kesehatan. Pedoman Teknis: Bangunan Dan Prasarana Puskesmas. Jakarta: Kemkes.go.id, 2013.

[11] A. Sofyan, Profil Daerah. Kutai Barat: BP3D Kutai Barat, 2017. 